\title{
A Portfolio as an Alternative Means of Presenting the University Student's Achievements
}

\author{
Regina Gennadyevna Sakhieva ${ }^{1}$, Suriya Irekovna Gilmanshina ${ }^{2}$, Iskander Rafailevich Gilmanshin ${ }^{2}$, Svetlana \\ Sergeyevna Kosmodemyanskaya ${ }^{2}$, Ilsia Rafailevna Akchurina ${ }^{2} \&$ Rimma Nadyrovna Sagitova $^{2}$ \\ ${ }^{1}$ Academy of Social Education, Russia \\ ${ }^{2}$ Kazan Federal University, Russia \\ Correspondence: Regina Gennadyevna Sakhieva, Academy of Social Education, Kazan, 420039, Russia. E-mail: \\ saxievarg@mail.ru
}

Received: September 26, 2014 Accepted: December 8, 2014 Online Published: December 30, 2014

doi:10.5539/ass.v11n7p162 URL: http://dx.doi.org/10.5539/ass.v11n7p162

\begin{abstract}
The article defines the objective, the tasks, the functions of the portfolio as an alternative means of presentation of the students' achievements in higher professional school. Nowadays there is no specified structure of the student portfolio, it may vary according to the targets, direction, educational profile and other factors. The paper considers the development of the structure of the undergraduate student portfolio. It also describes the principles of designing a portfolio, the main advantages and disadvantages of using a student portfolio in the university educational process. The practical relevance of this article reinforces the presented brief practical advice on creation a portfolio.
\end{abstract}

Keywords: portfolio, alternative means of presentation of the student's achievements, competence

\section{Introduction}

In the context of a new paradigm of the education development "lifelong education" the most demanded features of the students of higher education are mobility, dynamism, independence, commitment to efficient operation, ability to continuous self-development. These personality traits without doubt can be developed only in conditions of personal activity. To implement the new education strategy it is necessary to apply alternative means of presentation of the educational, research, public and other achievements of the university students (Gilmanshina \& Kamasina, 2013). A portfolio can become one of them.

The authors define the portfolio of a higher school student as a technology of determination, recording, storage, systematization, evaluation and presentation of real achievements and results of education, self-education, research, social and other activities of the student during a particular period of time, demonstrating the willingness of the student to self-development and self-realization (Sakhieva, 2011).

The purpose of the design and implementation of a portfolio in higher professional school is to provide significant educational and other achievements of the student, providing the track of his individual progress within its broader educational context, to demonstrate his ability to apply the acquired knowledge and skills in practice.

The portfolio tasks: to support and encourage educational motives of the student; to form the ability to set goals, to plan, to organize and be responsible for his own education and self-education activity; to design and implement the individual trajectory of the student's development; to demonstrate the dynamics of the personal growth and professional development of the student; to develop skills in reflective and assessment activities; to present an integrated assessment of the level of the student's readiness for future professional activities; to form the background for further successful self-actualization and self-realization in society. (Tregubova, Sakhieva, \& Masalimova, 2008).

The main functions of the portfolio are: motivational-presentational (to improve motivation for activity, to represent the results of the student's individual trajectory development in dynamics); educational- formative (to acquire new knowledge, skills, and competences, to develop creative activity experience ); projective- modeling (to design the student's individual educational path and the model of professional development); reflexive-evaluative (overall integrative assessment of the educational, professional and personal achievements 
of the student, the level of his readiness for future professional activity, gaining experience in the organization of reflection and self-assessment).

\section{Methodological Framework}

The principles of designing a portfolio are:

- Complexity (versatile evaluation by means of various forms of the performance presentation (the documents, works, reviews, expert opinions, etc.);

- Reliability (correspondence of the submitted materials to the true state of affairs);

- Continuity (the submitted documents should reflect the extension of the activity areas, the student's development dynamics);

- Optimality (designing a portfolio is not a goal in itself, it should contribute to the formation and development of universal cultural and professional competences of the student).

\section{Results}

\subsection{The Structure of a Student Portfolio (in Terms of Psycho-Pedagogical Training Areas)}

The structure of a student portfolio includes the following sections:

Section 1: General information about the student

- Summary (volume $1 \mathrm{p}$.)

- Autobiography (volume 1 p.)

- Introduction (in which the student explains what materials are included in the portfolio, and justifies the inclusion of these particular materials as the evidence of universal cultural and professional competencies. Volume - up to $3 \mathrm{p}$.)

Section 2: The results of the academic activities

- The results of the basic education program acquirement and formation of the universal cultural and professional competencies (a copy of the student's record or rating book, etc.);

- The results of the knowledge checkup;

- The results of the academic competitions;

- The certificates of passing various tests (including Internet-testing), etc.

This section of the portfolio is intended for certain academic disciplines, training courses or educational modules and, moreover, it contains subsections: storages where the students collect the material obtained from the teachers; the textbook and other educational sources, the patterns and work manuals, the evaluation criteria, the sheet of the performed independent work; the worksheets to help to perform unsupervised work; the registered stages of work performing - a sample, a draft, the completed work, the teacher's assessment.

\section{Section 3: Educational and Methodological Activity}

- "Cicada quotes" - the quotes of great men about the science and its subject;

- "The bibliography of the studied publications in various disciplines" - the bibliography of publications (books, articles, theses, etc.) in the studied subjects with a brief summary of each publication;

- The materials of various tests, techniques;

- Different training materials;

- Creation of visual and didactic materials in terms of various disciplines, psychological and educational problems;

- Working up a variety of graphic works, charts, tables, drawings in terms of various disciplines and psychological-pedagogical problems;

- Creating educational slide films;

- Miscellaneous materials for training and work practices;

- Developing different practical problem situations and their solutions;

- Developing recommendations, memos for educational psychologists, psychologists, teachers, parents, children, adolescents in terms of various psychological and educational problems; 
- Making up vocabularies for different disciplines, subjects and issues;

- Developing remedial development programs;

- Developing personal methods and techniques under the guidance of the supervisor;

- Developing personal models of psycho-pedagogical support of the educational process and the models developed with the supervisor, etc.

This section of the portfolio is also devoted to a certain academic discipline, a training course or an educational module.

At the end of this section it is necessary to choose the most significant educational and methodical work and justify its choice.

Section 4: Research activity

Compulsory work:

- Testing results (a copy of the title page with evaluation, a table of contents);

- Coursework / projects according to the years of education (copy of the cover sheet with evaluation, a table of contents, introduction);

- Graduation thesis (thesis) (a copy of the cover sheet with the evaluation, a table of contents, introduction).

Additional work:

- Reports in different disciplines;

- Speeches / presentations at the scientific conferences, seminars of various levels (faculty, university, national, regional, international, etc.)

- The list of the scientific research publications (filed according to the requirements);

- The works participated in grants competitions, scientific research competitions of various levels;

- The research and development activities as a co-author in the research and experimental work or in a temporary research team.

At the end of this section it is necessary to point out the most significant research work and justify its choice.

Section 5: Extracurricular activities

5.1. The extracurricular activities on the instruction of the group, department, faculty, educational institution:

- Participation in designing the materials collection, the group, department, faculty, institution booklets;

- Creation of a slide film about the group, department, faculty, educational institution;

- Creation and publishing the student newspapers;

- Participation in a psycho-pedagogical group / volunteer movement, etc..;

- Participation in charitable activities;

- Participation in various promotions;

- Participation in sports and recreational activities;

- Participation in career-oriented work and its results;

- Participation in various social activities of the group, department, faculty, institution, etc.

5.2 Extracurricular activities of the city, regional, national, international level:

- Participation in volunteering;

- Participation in various promotions;

- Participation in sports and recreational activities;

- Participation in the activities of various children's centers;

- Participation in the activities of social movements, organizations, funds, etc.;

- The development of social projects, programs, scripts, etc.;

- Activities in the creative groups, sports clubs, etc.;

- Participation in various competitions, festivals, etc. (contest "Student Spring", etc..) 
At the end of this section it is necessary to point out the most significant extracurricular activity and justify its choice.

\section{Section 6: External evaluation}

- The reviews of the competitive work, individual and group projects, term papers and graduation thesis (theses) made by the scientific supervisor and reviewers;

- The character references of the student presented by the supervisors of various training practices;

- The recommendations of the State Certification Commission for implementation of the graduation thesis results into the educational process of various educational institutions;

- The character reference of the student submitted by the educational institution;

- The Recommendations of the Department and the Faculty Council for entering the Master's or postgraduate program etc.;

- Testimonial letters to the employer, etc.

Section 7: Self-analysis, self-evaluation

- A final student's essay about the acquired competencies, experiences, creative activities in the process of studying in the institution and professional activity (if relevant).

Section 8. Further self-development strategy

In this aspect, the student determines the future plans, further ways of self-improvement, self-development, self-actualization, that is especially important in the context of a new paradigm of the education development "lifelong education".

Applications. The documents confirming the student's achievement

- The copies of the reviews, comments, letters, certificates, diplomas, etc.

\subsection{Brief Practical Advice on Creation of a Portfolio}

- It is advisable to render the portfolio sections suitable for particular activities;

- Each element of the portfolio should be dated in order to follow the dynamics of the student's development;

- It is desirable to provide the portfolio with the photographs showing its contents;

- It is advisable to use two types of portfolio: a working one, in which all the available materials are collected; a demonstration one in which the materials that reflect the educational, research, social and other student's achievement, progress in his personal and professional development are collected.

\section{Discussions}

The research on the problem of developing and using a portfolio are being carried out in different directions:

- the analysis of foreign experience of portfolio use in the educational process is represented in the works of V. K. Zagvozdkin (2004), M. Kimball (2002), T. G. Novikova, A. S. Prutchenkov, E. E. Fedotova (2005); J. Strivens (2007);

- portfolio as one of the modern evaluation means of the education results is considered in studies of N. F Efremova (2012), V. I. Zvonnikov (2007), A. P. Cherniavskaya (2008) and others;

- the problem of the formation, development and evaluation of the student's competencies by means of a portfolio is discussed in the scientific writings of H. Keurulaynen (2007), M. S. Mukhina (2009), O. V. Nikiforov (2007), N. M. Savina (2008);

- the use of a portfolio in the professional training of the students in pedagogics are devoted the studies of N. V. Zelenko, A. G. Mogilevskaya (2009), L. S. Kolodkina (2008), A. A. Semenov (2008), E. H. Tazutdinova (2010) and others;

- the implementation of a professional teacher's portfolio in his teaching activities was studied in the writings of L. P. Makarova (2010), M. A. Pinskaya (2009), M. M. Potashnik (2009), L. Pronina (2009).

The problem of designing and using a portfolio as an alternative means of presentation of higher school students' achievements in terms of psycho-pedagogical training areas is the area of theoretical and practical knowledge that has not been thoroughly studied yet. 


\section{Conclusion}

Therefore, the portfolio is an alternative means of presenting the university student's achievements: it reflects the results of an individual educational activity of the student, the level of self-organization, the level of the development of the universal cultural and professional competencies that fully characterizes the student's identity, his information culture, communication characteristics, reflects his consistent and long-term educational results thus compensating the effect of an odd success or failure in the exam.

The authors pay attention to the fact that in the process of working over a portfolio it is not the result of creative endeavor that is important but the process itself, and those skills, competencies and experience that the student acquires in the process of portfolio making. While designing and implementing a portfolio the students obtain such knowledge and skills that build the basis for the formation of universal cultural and professional competencies: general (systematization, generalization, comparison, classification and others ); projecting (choice and setting the goals, operations sequencing and assessing, planning, choice of work methods and others ); research (the ability to clearly identify the problem, formulate a hypothesis, set the research tasks, pick appropriate methods, identify the ways of solving the research goals, etc.); communication (the ability to work in a team, interact with others, etc.); organizational (ability to conduct business records, find the necessary data, use a variety of ways to work with the information and its sources, etc.); reflexive (the ability to analyze and be engaged in self-reflection over the activities, to compare it with the standards and thereafter improve it and to take the lead to achieve personal progress); the skills of self-control and self-esteem (self-criticism, the ability to evaluate and adjust personal activities, etc.).

The advantages of the portfolio use of in the educational process of higher education institution can be identified as: first, in contrast to the traditional approach, which separates the teaching, learning and assessment, the portfolio combines the three components of the learning process; secondly, it stimulates the students' activity and independence; Third, it mostly allows to present the student's achievements in various activities; Fourth, allows to combine both quantitative and qualitative evaluation of the student's abilities by analyzing a variety of the activities products; Fifth, it is not only the score that is encouraged, but also self-esteem, inter-evaluation of the student, as well as self-examination and self-control; Sixth, it is a form of continuous evaluation in the context of the concept "learning throughout life." The major disadvantages of the portfolio use in the educational process of higher professional schools are: the complexity of the evaluation process; vagueness in defining the scope and criteria for the portfolio evaluating.

The portfolio as a dynamic, flexible, alternative means of presentation of the higher education students achievements can be easily integrated into professional and service system performance and assessing, that allows early formation of the professionally relevant skills and competences of the individual.

\section{References}

Cherniavskaya, G. P., \& Grechin, B. S. (n. d.). Modern means of evaluating learning outcomes (p. 98). Yaroslavl. Yaroslavl State Pedagogical Institute.

Efremova, N. F. (2012). Competence in education: The formation and evaluation (p. 416). Moscow. National Education.

Gilmanshina, S. I., \& Kamasina, A. R. (2013). To prepare students for professional work of the teacher in accordance with the requirements of the standard of the third generation. International Journal of Experimental Education, 4, 85-88.

Keurulaynen, H. E. (2007). E-Portfolio as a tool of the assessment of competence. Higher Education in Russia, 4, 100-103.

Kimball, M. (2002). The Web Portfolio Guide: Creating Electronic Portfolios for the Web. Texas (p. 208). Tech University.

Kolodkina, L. S. (2008). Portfolio of students in teaching practices. School technology, 3, 129-133.

Makarova, L. P. (2010). Teacher`s Portfolio (p. 102). Volgograd: Teacher.

Mukhina, M. S. (2009). Using portfolio in the development of professional competencies of students. Vocational Education, 10, 30-31.

Nikiforov, O. V. (2007). Competence component in the structure of the evaluation of graduates of pedagogical high school (p. 25). Author's abstract of Dissertations of candidate of pedagogical sciences. Moscow.

Novikova, T. G., Prutchenkov, A. S., \& Fedotova, E. E. (2005). International experience of using portfolio. 
Education, 9, 151-154.

Pinskaya, M. A. (2009). Teacher's Portfolio. Moscow (p. 32). Chistye Prudy.

Potashnik, M. M. (2009). Teacher's Portfolio: Possible benefits and possible harm. Education, 6, 99-103.

Pronina, L. A. (2009). Teacher's Portfolio. Pupils' Upbringing, 4, 15-20.

Sakhieva, R. G. (2011). Vocational school student portfolio (p. 5). Kazan. Academy of Social Education.

Savina, N. M. (2008). Innovative competence-oriented educational technologies in vocational education. Vocational professional education, 4, 2-5.

Semenov, A. A. (2008). Portfolio as a means of the evaluation of graduates of pedagogical high school. Higher education today, 12, 66-70.

Strivens, J. (2007). Efficient assessment of portfolio: A report for Peter Knight, Director, Institute of Educational Technology (p. 32). The Open University.

Tazutdinova, E. H. (2010). Portfolio in the training of students for future educational activities: the dissertation of the candidate of pedagogical sciences (p. 200). Kazan.

Tregubova, T. M., Sakhieva, R. G., Masalimova, A. R., Beljakin, A. M., \& Tazutdinova, E. H. (2008). Academic mobility of students in higher education: National and international experience of its formation (p. 106). Kazan. Fatherland.

Zagvozdkin, V. K. (2004). The role of the portfolio in the learning process. Some psihologo-pedagogical aspects (on the basis of foreign sources). Psychological Science and Education, 4, 5-10.

Zelenko, N. V., \& Mogilevskaya, A. G. (2009). Portfolio of the future teacher. Standards and monitoring in education, 1, 61-63.

Zvonnikov, V. I. (2007). Modern means of evaluating the results of training (p. 224). Moscow. Academy.

\section{Copyrights}

Copyright for this article is retained by the author(s), with first publication rights granted to the journal.

This is an open-access article distributed under the terms and conditions of the Creative Commons Attribution license (http://creativecommons.org/licenses/by/3.0/). 